\title{
Using Exploratory and Confirmatory Factor Analysis in Measuring Gender and Women's Empowerment in Egypt
}

\author{
Eman Ahmed Aly Ismail \\ College of International Transport \& Logistics \\ Arab Academy for Science, Technology \& Maritime Transport \\ Smart Village Campus \\ eaismail@yahoo.com,emanismail@aast.edu
}

\begin{abstract}
This paper aims to measure Gender and Women's empowerment in Egypt. Based on Egypt Labor Market Panel Survey of 2012 (ELMPS, 2012), where a total of 6920 married women between the ages of 19 to 49 years old were selected. Findings from the Exploratory Factor Analysis revealed that five factors were extracted and explained $68.028 \%$ of the cumulative variance. Making decisions had the greatest effect on empowering Egyptian women, whereas seeking help from relatives had the least effect Then, a Confirmatory Factor Analysis was used to test the hypothesis which revealed that there were relationships between the variables and their latent constructs. Also, a MannWhitney test used to measure the women's empowerment for all the 17 variables that were all statistically significant. Finally, some demographic variables were analyzed with regards to the women's empowerment and revealed that both older and more advantages women were more empowered than younger ones, whereas education seemed to have no effect in empowering Egyptian women.
\end{abstract}

Keywords: Empowerment, gender, equality, exploratory factor analysis, EFA, confirmatory factor analysis, CFA, Egypt.

\section{Introduction}

There is evidence that some gender norms influence the empowerment of married women. These norms are related to the decision making within the family, which includes who has the final say in some of the daily life routine, such as household purchases, buying clothes for children, going to the local heath unit or to the doctor, 
and dealing with the children's school. In addition to that, the ability of women to go alone and/or without permission to some places has an influence on women's empowerment. Indeed, Kabeer, in 1999, identified that the preconditions of empowerment include economic and many human and social resources. This means that the economic and gender components of empowerment are both essential, as well as pre-conditions. However, this study only focuses on gender norms, which are preconditions of empowerment.

The objective of this paper is to examine the association between gender norms and married women's empowerment in Egypt. Firstly, the study shall use the Explanatory Factor Analysis (EFA) and Confirmatory Factor Analysis (CFA), to determine the number of factors and their relations. Secondly, it shall construct a weighted measure of women's empowerment to the results, which compares them to simple scale measures.

\section{Literature Review}

According to Kabeer (2005), the third goal of the eight Millennium Development Goals (MDG), on gender equality and women's empowerment, was too narrow. That was because gender and empowerment included multidimensional aspects that could not be reduced- as the third goal suggested. He explored the concept of empowerment using three dimensions, agency, resources, and achievements. The findings of the study revealed that agency had a positive and a negative side, where resources refer to the medium where agency was exercised, and achievements refer to the outcomes.

Williams (2005), used a theoretical model of women's empowerment in the rural Bangladesh, and then tested it using CFA of the data obtained from Matlab Health and Socioeconomic Survey (MHSS) that was conducted in 1996. The study suggested six interrelated dimensions of empowerments, which included making decisions, being not modest, making small purchases, visiting women, making large purchases, and using public transportation. Then the results of the CFA were used to construct weighted measures of women's empowerment. The importance of the study comes from that measuring gender and women's empowerment enables demographers to study their impact on the society.

Huis et al. (2017) proposed a three dimensions model of women's empowerment in the field of microfinance services. These dimensions were: (1) Personal Empowerment (i.e. self-esteem and self-confidence), (2) Relational Empowerment (which included the relation with a partner, family or social networks), and (3) Societal Empowerment (which included the indices that map gender gaps across countries). The study also proposed that time and culture were important factors that influenced women's empowerment (e.g. one microfinance intervention may have a positive impact on women's empowerment in a certain nation but may have a negative impact in another nation). 
Abdel Mowla (2009) concluded that some other policies needed to be considered to support women's empowerment. These policies included flexible working time, accessible and affordable daycare centers, and effective women's entrepreneurship policy. The study also stressed on the importance of improving the quality of education in Egypt, especially among girls.

\section{Data and Methodology}

EFA and CFA became increasingly popular in social and behavioral sciences. The main goal of EFA is to determine the minimum number of factors needed to reproduce the item correlation matrix (Izquierdo et al., 2014), while CFA allows to test that the factors and their latent construct are related (Suhr, 2006). The current study applied both EFA and CFA; based on Egypt Labor Market Panel Survey of 2012 (ELMPS, 2012). This study only selected married women, between the ages of 19 to 49 years old, since some of the used questions were about women's children. Accordingly, the total number of women were 6920. The results of CFA were then used to construct weighted measures of Egyptian women's empowerment that were then compared to the simple scale measures.

\section{Discussion and Results}

In 2016, the United Nations launched the sustainable goal number 5, which aimed to achieve gender equality and to empower all women and girls. The empowerment definition, according to the World Bank, is "the process of enhancing an individual's or group's capacity to make purposive choices and to transform those choices into desired actions and outcomes" (p. 5). While Kabeer (1994) defined women's empowerment as 'the expansion in people's ability to make strategic life choices in a context where this ability was previously denied to them" (p. 2-3). However, the expansion of women's capabilities (i.e. the access to education and skills and the access to microfinance services) does not imply empowering them, since power is gendered in many societies, especially in the developing countries (Huis et al., 2017). For example, the access to education and training does not necessarily translate into access to jobs. Also, the access to microfinance services does not mean empowering women. Moreover, besides the individual's factors, there are the societal factors as well. That are either close to women, such as husband and family, or the larger social context, which are crucial in studying women's empowerment. Most researches about women's empowerment agreed that it is multidimensional and includes multiple factors.

According to the Global Gender Gap Index in 2018, the Egyptian rank was 135 out of 149 countries, compared to its rank of 109 in 2006, when the index was first introduced. This index was constructed to rank countries according to their gender gaps and equality, rather than women's empowerment. The index was composed of 
four sub-indexes; economic participation and opportunity, educational attainment, health and survival, and political empowerment, which were composed of 14 indicators. The Egyptian general gender gap score was $61.4 \%$, which means there is still a $38.6 \%$ gap to close. However, the global gender gap score was $68 \%$, which means that there is still a gap of $32 \%$ to close. Egypt improved its educational attainment (the score was 97.5\%). Also, the health and survival score were $97.4 \%$. The global gender parity- which refers to the Ratio of female to male values for a given indicator- on the two previous sub-indexes; educational attainment and health and survival, was almost achieved, where the gaps were $5 \%$ and $4 \%$ respectively. On the other hand, the score of economic participation and opportunity was $42.1 \%$ in Egypt, while globally $58 \%$ of this gap has been closed. Also, the political empowerment score in Egypt was $8.7 \%$, however, the global gender gap was still the widest, where the global political gender gap was $23 \%$.

According to the United Nations Development Programme (UNDP, 2018), and as of the year 2018, countries were divided into five groups, by absolute deviation from gender parity in Human Development Index (HDI), Egypt was in the human development medium and its rank was 115 among 189 countries. The Egyptian HDI value, in 2017, was 0.696 , up about $27.47 \%$ from 0.546 , in 1990 . While the global HDI value was 0.728 and 0.598 , in 2017 and 1990 respectively (up about $21.7 \%$ ). Since 2010, the Inequalities-adjusted Human Development Index (IHDI) was published to show the difference between it and the HDI (the greater the inequality, the greater the difference). The inequalities reflect unequal opportunity in education, health, and income. In Egypt, the average loss in the HDI value due to inequality was about $29.2 \%$ - the HDI and IHDI were 0.696 and 0.493 , in 2017 , respectivelyand the difference was (-10) from the HDI rank. While the global HDI fell from 0.728 to 0.582 in 2017 (about 20\% loss because of inequality). The inequality in education $(36.9 \%)$ contributed the most to the Egyptian loss in HDI, followed by the inequality in income (36.3\%), and life expectancy $(11.6 \%)$. Globally, the inequality in income was $22.6 \%$ followed by education $22.0 \%$, and life expectancy 15.2\%. (UNDP, 2018).

The Study's Conceptional Framework: This study used Egypt Labor Market Panel Survey (ELMPS, 2012) to measure women's empowerment in Egypt. In a special section of the ELMPS, in 2012, women from 15 to 49 years old of age were asked about their behaviors and attitudes regarding dealing with their empowerment. This study only selected the married ones to be included in measuring gender and empowerment, since some of the questions dealt with their children. Hashemi and Schuler (1993) designed a multi-dimensional theoretical model, which included six dimensions of empowerment, according to the women's daily activities. Also, Williams (2005) developed a six dimensions theoretical model of empowerment, which modified the former model according to the Health and Socioeconomic Status Survey (MHSS) 1996, conducted in rural Bangladesh. This study used a 
combination of the former two frameworks, according to the available data of ELMPS (2012). The framework emerged from the EFA that was composed of five dimensions that covered the norms that define the behavior of the Egyptian women; those five dimensions were interrelated (Table 1 below).

The first dimension of empowerment was the process of decision-making within the household. This dimension consisted of six variables that clarified who has the final say on some decisions within the household. This dimension combined the participation in the decision-making process and the control over money and purchases through six questions. The answers to those questions were either that the woman had the final say, or herself and the others, or just the others- the others included husband or/and in laws. However, these questions reflected some of the woman's attitudes/ behaviors, and not her feelings or approvals about these attitudes. Those questions covered different types of behaviors, three of them were concerning who has the final say about going for treatment, taking her children to the local health center/doctor, or visiting her family or some relatives. The other three questions covered the decision-making process of purchasing clothes for herself, or purchasing clothes for her children, and making large household purchases. The women who had the final say were the most empowered.

The second dimension was mobility, which included some actions that make women leave the house. This dimension consisted of three variables, whether the women can go to some places, such as going to the local health center/doctor, taking the children to local health center/ doctor, or visiting some family members or friends alone without permission or after having permission or could not go alone. The women who could go without permission were the most empowered.

The third dimension was dealing with the children's school and it included two variables. Those variables were sending the children to school daily and dealing with the children's school and teachers. The answer to those questions were either the woman has the final say, or herself and the others, or just the others- the others included husband or/and in laws. The women who had the final say were the most empowered.

The fourth dimension was seeking the relatives' help and it included three variables. This help was in a form of offering a place to stay in for a night, offering money if needed or visiting a nearby family or relative for a day. And the answer to those questions was yes or no. Women who answered yes were the most empowered.

The final dimension was the daily decisions within the household. This dimension included three variables; the first two dealt with daily purchases for the household and deciding on what to be cooked daily, and the answers to those questions were either that the woman has the final say, or herself and the others, or just the others- the others included husband or/and in laws. As for the third question, it was whether the women could go to the market by their own, or whether a 
permission was needed. Higher scores reflected greater empowerment.

Table 1: Dimensions of Empowerment

\begin{tabular}{|c|c|c|}
\hline $\begin{array}{l}\text { Dimension } \\
\text { (factors) }\end{array}$ & ELMPS 2012 Questions & Answers \\
\hline $\begin{array}{l}\text { Make } \\
\text { decisions } \\
\text { (FI) }\end{array}$ & $\begin{array}{l}\text { X } 7302-5 \text { Going to the local health } \\
\text { center/doctor. } \\
\text { X 7302-7 taking the children to the health } \\
\text { center/doctor. } \\
\text { X } 7302-3 \text { visiting family, relatives or } \\
\text { friends. } \\
\text { X } 7302-6 \text { buying clothes to yourself. } \\
\text { X 7302-1 making large household } \\
\text { purchases. } \\
\text { X } 7302-10 \text { buying clothes and other needs } \\
\text { for children }\end{array}$ & $\begin{array}{l}\text { Who has the final say: } \\
\text { 3-you alone. } \\
\text { 2-you and others } \\
\text { (husbands and/or } \\
\text { in laws). } \\
\text { 1-others (husband } \\
\text { and/or in laws). } \\
\text { 0-not applicable. }\end{array}$ \\
\hline $\begin{array}{l}\text { Mobility } \\
\text { (F2) }\end{array}$ & $\begin{array}{l}\text { X 7305-3 taking the children to the health } \\
\text { center/doctor. } \\
\text { X 7305-2 Going to the local health center/ } \\
\text { doctor. } \\
\text { X } 7305-4 \text { Visiting house of relatives or } \\
\text { friends in the neighborhood. }\end{array}$ & $\begin{array}{l}\text { 3-go alone without } \\
\text { permission. } \\
\text { 2-need permission. } \\
\text { 1-don't go alone. } \\
\text { 0-not applicable. }\end{array}$ \\
\hline $\begin{array}{l}\text { Dealing with } \\
\text { the } \\
\text { children's } \\
\text { school (F3) }\end{array}$ & $\begin{array}{l}\text { X 7302-9 Sending children to school on } \\
\text { daily basis. } \\
\text { X 7302-8 Dealing with children's school } \\
\text { and teachers. }\end{array}$ & $\begin{array}{l}\text { Who has the final say: } \\
\text { 3-you alone. } \\
\text { 2-you and others } \\
\text { (husbands and/or in } \\
\text { laws). } \\
\text { 1-others (husband } \\
\text { and/or in laws). } \\
\text { 0-not applicable. }\end{array}$ \\
\hline $\begin{array}{l}\text { Seeking for } \\
\text { relatives } \\
\text { help }(\mathrm{F} 4)\end{array}$ & $\begin{array}{l}\text { X 7307-1 If you have a problem and } \\
\text { needed help, is there any family or relative } \\
\text { provide you a place to stay for night. } \\
\text { X } 7307-2 \text { If you have a problem and } \\
\text { needed help, is there any family or relative } \\
\text { help you financially. } \\
\text { X } 7306 \text { Is there anyone of your family or } \\
\text { relatives } \\
\text { living nearby so you can visit and come } \\
\text { back on } \\
\text { the same day. }\end{array}$ & $\begin{array}{l}\text { 2-yes. } \\
\text { 1-no. } \\
\text { 0-NA. }\end{array}$ \\
\hline $\begin{array}{l}\text { Daily } \\
\text { decision } \\
\text { within }\end{array}$ & $\begin{array}{l}\text { X 7302-2 Making household purchases for } \\
\text { daily needs. } \\
\text { X 7302-4 Deciding every day meal. }\end{array}$ & $\begin{array}{l}\text { Who has the final say } \\
\text { (X 7302-2 and X7302- } \\
4 \text { ): }\end{array}$ \\
\hline
\end{tabular}




\begin{tabular}{|c|c|c|}
\hline $\begin{array}{l}\text { the } \\
\text { household } \\
\text { (F5) }\end{array}$ & X 7305-1Going to the local market. & $\begin{array}{l}\text { 3-you alone. } \\
\text { 2-you and others } \\
\text { (husbands and/or in } \\
\text { laws). } \\
\text { 1-others (husband } \\
\text { and/or in laws). } \\
\text { 0-not applicable. } \\
\text { X7305-1 : } \\
\text { 3-go alone without } \\
\text { permission. } \\
\text { 2-need permission. } \\
\text { 1-don't go alone. } \\
\text { 0-not applicable. }\end{array}$ \\
\hline
\end{tabular}

Theoretical dimensions of Egyptian women's empowerment were based on EMPLS (2012) and the theoretical model was developed by Hashemi and Schuler (1993).

\section{Using EFA and CFA to test the model of women's empowerment:}

First, EFA was applied using SPSS 24. Table 2 below shows that the KaiserMeyer-Olkin (KMO) value, which was used to confirm the adequacy of the sample and the ability of the model to extract the latent variables, was equal to 0.785 . Bartlett's test of Sphericity, which was also used to assess the model adequacy was statistically significant.

Table 2: Measuring of sampling adequacy

\begin{tabular}{|c|c|c|}
\hline \multicolumn{2}{|c|}{ KMO and Bartlett's Test } \\
\hline Kaiser-Meyer-Olkin Measure of Sampling & \multirow{2}{*}{0.785} \\
\hline Adequacy. & Approx. Chi- & \multirow{2}{*}{5} \\
\hline Bartlett's Test of & Square & \\
\hline \multirow{2}{*}{ Sphericity } & Df & 136 \\
\cline { 2 - 3 } & Sig. & 0.000 \\
\cline { 2 - 3 } & &
\end{tabular}

Table 3 presents the rotated component matrix- by using Varimax rotation method by Kaiser, which was applied to extract the principle component matrix and the factors that had eigenvalues greater than one. It shows that five factors were retained as they all explained $68.028 \%$ of the cumulative variance $(17.748 \%$, $14.628 \%, 13.088 \%, 11.670 \%$ and $10.894 \%$ for each factor respectively).

Table 4 illustrates the correlations between the 17 items and the five factors. The values were arranged from largest to smallest. 
Table 3: Results from EFA

\begin{tabular}{|c|c|c|c|c|c|c|c|c|c|}
\hline \multicolumn{10}{|c|}{ Total Variance Explained } \\
\hline \multirow[b]{2}{*}{ Component } & \multicolumn{3}{|c|}{ Initial Eigenvalues } & \multicolumn{3}{|c|}{$\begin{array}{c}\text { Extraction Sums of } \\
\text { Squared Loadings }\end{array}$} & \multicolumn{3}{|c|}{$\begin{array}{l}\text { Rotation Sums of } \\
\text { Squared Loadings }\end{array}$} \\
\hline & Total & $\begin{array}{c}\% \text { of } \\
\text { Varianc } \\
\mathrm{e}\end{array}$ & \begin{tabular}{|c|} 
Cumula \\
tive \\
$\%$
\end{tabular} & Total & \begin{tabular}{|c}
$\%$ of \\
Varianc \\
$\mathrm{e}$
\end{tabular} & $\begin{array}{c}\text { Cumula } \\
\text { tive } \\
\%\end{array}$ & Total & $\begin{array}{c}\% \text { of } \\
\text { Varianc } \\
\mathrm{e}\end{array}$ & $\begin{array}{c}\text { Cumula } \\
\text { tive } \\
\%\end{array}$ \\
\hline 1 & 4.826 & 28.390 & \begin{tabular}{|l|}
28.390 \\
\end{tabular} & 4.826 & 28.390 & 28.390 & 3.017 & 17.748 & \begin{tabular}{|l|}
17.748 \\
\end{tabular} \\
\hline 2 & 2.225 & 13.090 & 41.481 & 2.225 & 13.090 & 41.481 & 2.487 & 14.628 & 32.376 \\
\hline 3 & 1.802 & 10.599 & 52.079 & 1.802 & 10.599 & 52.079 & 2.225 & 13.088 & 45.464 \\
\hline 4 & 1.609 & 9.463 & 61.542 & 1.609 & 9.463 & 61.542 & 1.984 & 11.670 & 57.134 \\
\hline 5 & 1.103 & 6.486 & 68.028 & 1.103 & 6.486 & 68.028 & 1.852 & 10.894 & 68.028 \\
\hline 6 & 0.832 & 4.892 & 72.920 & & & & & & \\
\hline 7 & 0.684 & 4.026 & 76.946 & & & & & & \\
\hline 8 & 0.648 & 3.810 & \begin{tabular}{|l|}
80.756 \\
\end{tabular} & & & & & & \\
\hline 9 & 0.594 & 3.494 & 84.250 & & & & & & \\
\hline 10 & 0.546 & 3.211 & 87.460 & & & & & & \\
\hline 11 & 0.529 & 3.112 & 90.573 & & & & & & \\
\hline 12 & 0.437 & 2.571 & 93.144 & & & & & & \\
\hline 13 & 0.370 & 2.175 & 95.318 & & & & & & \\
\hline 14 & 0.344 & 2.021 & 97.340 & & & & & & \\
\hline 15 & 0.195 & 1.150 & \begin{tabular}{|l|}
98.490 \\
\end{tabular} & & & & & & \\
\hline 16 & 0.148 & 0.869 & 99.358 & & & & & & \\
\hline 17 & 0.109 & 0.642 & 100.000 & & & & & & \\
\hline
\end{tabular}

Extraction Method: Principal Component Analysis.

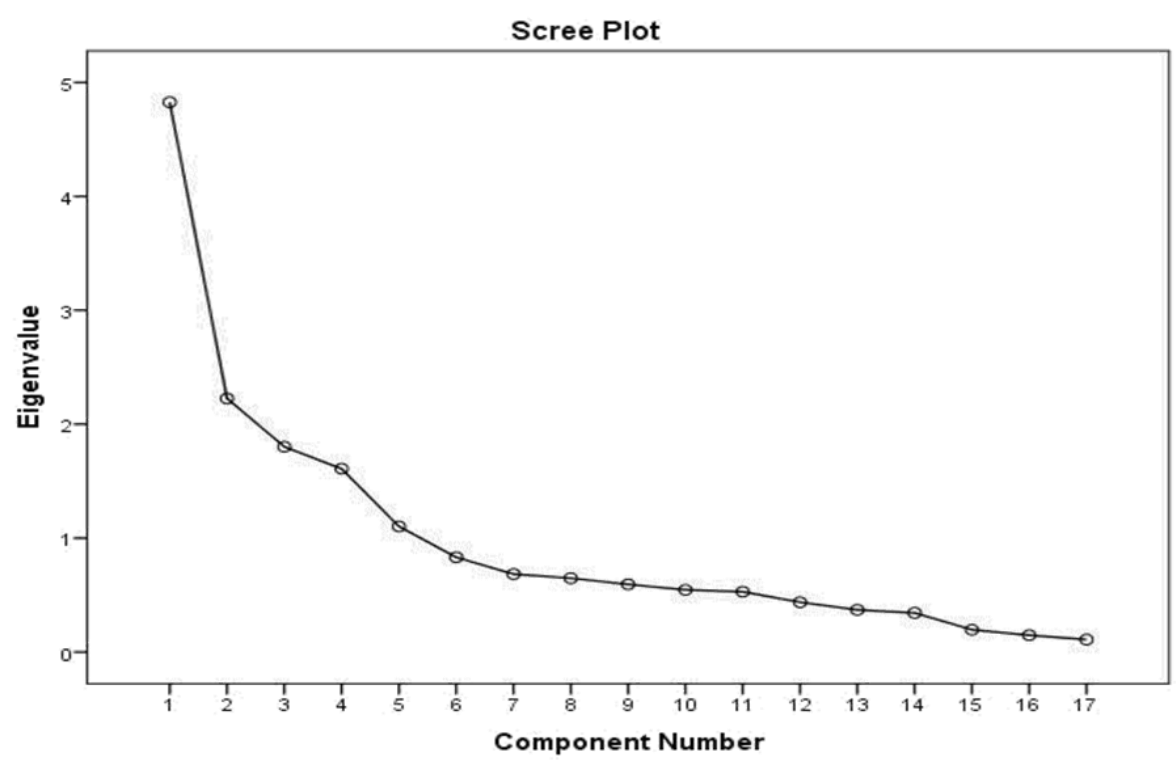

Fig. 1: Score plot. 
Table 4: The correlation between the 17 items

\begin{tabular}{|c|c|c|c|c|c|c|c|}
\hline \multicolumn{7}{|c|}{ Rotated Component Matrix } \\
\hline & & & & \multicolumn{2}{|c|}{ Factors } & & \\
\hline Items & 1 & & 2 & & 3 & 4 & 5 \\
\hline x5 & & 0.818 & & & & & \\
\hline x7 & & 0.749 & & & & & \\
\hline x3 & & 0.717 & & & & & \\
\hline x6 & & 0.682 & & & & & \\
\hline x1 & & 0.516 & & & & & \\
\hline x10 & & 0.487 & & & & & \\
\hline x7305_3 & & & & 0.883 & & & \\
\hline x7305_2 & & & & 0.754 & & & \\
\hline x7305_4 & & & & & 0.938 & & \\
\hline x8 & & & & & 0.931 & & \\
\hline x9 & & & & & & 0.939 & \\
\hline q7307_1 & & & & & & 0.680 & \\
\hline q7307_2 & & & & & & & 0.793 \\
\hline q7306 & & & & & & & 0.792 \\
\hline x2 & & & & & & & \\
\hline x4 & & & & & & & \\
\hline x7305_1 & & & & & & & \\
\hline
\end{tabular}

Extraction Method: Principal Component Analysis.

Rotation Method: Varimax with Kaiser Normalization.

a. Rotation converged in 5 iterations.

Figure 1 above shows the Scree plot, which determines the number of accepted factors (five factors). According to Kaiser, the factor is accepted when its Eigenvalue is greater than one and is rejected if the eigenvalue is less than one.

Table 5: Chi-square value

Chi-square $=395.85$

Degrees of freedom $=80$

Probability level $=.001$

As shown in Table 5, CFA was then conducted using AMOS 22, based on the EFA results, the minimum chi-square achieved was 395.85- the lower values indicate better fit- and is statistically significant.

Table 6 shows the regression weights for each factor and the variables included in it, and as estimated by CFA, were all statistically significant. Then Table 7 shows the standardized regression weights (CFA) compared with the rotated matrix (EFA). The CFA is more accurate than the EFA, since it considers the errors, and the relationships between the errors and the variables. 
Table 6: Regression weights (CFA)

\begin{tabular}{|c|c|c|c|c|c|c|l|}
\hline & & & Estimate & S.E. & C.R. & P & Label \\
\hline x7302_3 & $<---$ & F1 & 1 & & & & \\
\hline x7302_5 & $<---$ & F1 & 1.401 & 0.031 & 45.604 & $* * *$ & \\
\hline X7302_6 & $<---$ & F1 & 1.107 & 0.025 & 44.051 & $* * *$ & \\
\hline X7302_7 & $<---$ & F1 & 1.284 & 0.028 & 45.701 & $* * *$ & \\
\hline x7302_1 & $<---$ & F1 & 0.627 & 0.023 & 27.53 & $* * *$ & \\
\hline x7302_10 & $<---$ & F1 & 1.300 & 0.034 & 38.58 & $* * *$ & \\
\hline x7305_3 & $<---$ & F2 & 1 & & & & \\
\hline X7305_2 & $<---$ & F2 & 0.952 & 0.012 & 77.41 & $* * *$ & \\
\hline x7305_4 & $<---$ & F2 & 0.603 & 0.011 & 56.111 & $* * *$ & \\
\hline x7302_8 & $<---$ & F3 & 1 & & & & \\
\hline x7302_9 & $<---$ & F3 & 1.030 & 0.024 & 42.042 & $* * *$ & \\
\hline q7307_1 & $<---$ & F4 & 1 & & & & \\
\hline q7307_2 & $<---$ & F4 & 0.970 & 0.012 & 78.886 & $* * *$ & \\
\hline x7302_2 & $<---$ & F5 & 1 & & & & \\
\hline x7302_4 & $<---$ & F5 & 0.738 & 0.018 & 40.308 & $* * *$ & \\
\hline x7305_1 & $<---$ & F5 & 0.494 & 0.014 & 34.975 & $* * *$ & \\
\hline x7302_10 & $<---$ & F1 & 1.300 & 0.034 & 38.58 & $* * *$ & \\
\hline
\end{tabular}

Table 7: Comparison between the EFA and CFA

\begin{tabular}{|c|c|c|c|c|c|c|c|c|c|}
\hline \multicolumn{4}{|c|}{\begin{tabular}{|l|} 
Standardized Regression \\
Weights (CFA) \\
\end{tabular}} & \multicolumn{6}{|c|}{ Rotated Component Matrix (EFC) } \\
\hline & & & Estimate & \multirow{2}{*}{ items } & & & factors & & \\
\hline x7302_3 & $<--$ & $\mathrm{F} 1$ & 0.595 & & 1 & 2 & 4 & 3 & 5 \\
\hline x7302_5 & <--- & F1 & 0.838 & $\mathrm{x} 3$ & 0.717 & & & & \\
\hline x7302_6 & <--- & $\mathrm{F} 1$ & 0.622 & $\mathrm{x} 5$ & 0.818 & & & & \\
\hline x7302_7 & $<---$ & F1 & 0.718 & $\mathrm{x} 6$ & 0.682 & & & & \\
\hline x7302_1 & $<---$ & F1 & 0.420 & $\mathrm{x} 7$ & 0.749 & & & & \\
\hline x7302_10 & $<--$ & F1 & 0.647 & $\mathrm{x} 1$ & 0.516 & & & & \\
\hline$\times 7305 \_3$ & $<---$ & $\mathrm{F} 2$ & 0.910 & $\mathrm{x} 10$ & 0.487 & & & & \\
\hline x7305_2 & <--- & $\mathrm{F} 2$ & 0.876 & x7305_3 & & 0.883 & & & \\
\hline x7305_4 & <--- & $\mathrm{F} 2$ & 0.624 & x7305_2 & & 0.878 & & & \\
\hline x7302_8 & $<--$ & $\mathrm{F} 3$ & 0.936 & X7305_4 & & 0.754 & & & \\
\hline x7302_9 & $<--$ & F3 & 0.909 & $\mathrm{x} 8$ & & & 0.938 & & \\
\hline q7307_1 & $<--$ & $\mathrm{F} 4$ & 0.971 & $\mathrm{x} 9$ & & & 0.931 & & \\
\hline q7307_2 & $<--$ & $\mathrm{F} 4$ & 0.917 & q7307_1 & & & & 0.939 & \\
\hline q7306 & <--- & $\mathrm{F} 4$ & 0.468 & q7307_2 & & & & 0.930 & \\
\hline x7302_2 & $<--$ & F5 & 0.864 & q7306 & & & & 0.680 & \\
\hline x7302_4 & $<--$ & F5 & 0.685 & $\mathrm{x} 2$ & & & & & 0.793 \\
\hline x7305_1 & $<--$ & F5 & 0.546 & $\mathrm{x} 4$ & & & & & 0.792 \\
\hline
\end{tabular}


Table 8: Factor score weights (CFA)

\begin{tabular}{|c|c|c|c|c|c|}
\hline & F1 & F2 & F3 & F4 & F5 \\
\hline x7302_5 & $\mathbf{0 . 2 9 6}$ & -0.002 & 0.021 & 0.001 & 0.340 \\
\hline x7302_10 & $\mathbf{0 . 1 3 1}$ & 0.008 & -0.303 & 0.001 & 0.048 \\
\hline x7302_7 & $\mathbf{0 . 0 7 6}$ & -0.002 & 0.094 & 0.000 & -0.016 \\
\hline x7302_3 & $\mathbf{0 . 0 5 7}$ & -0.003 & 0.008 & 0.000 & -0.031 \\
\hline x7302_6 & $\mathbf{0 . 0 4 3}$ & 0.006 & 0.059 & 0.000 & -0.056 \\
\hline x7302_1 & $\mathbf{0 . 0 3 8}$ & -0.006 & 0.005 & 0.000 & -0.033 \\
\hline x7305_3 & 0.017 & $\mathbf{0 . 5 4 1}$ & -0.002 & 0.001 & -0.009 \\
\hline x7305_2 & 0.001 & $\mathbf{0 . 4 4 0}$ & 0.017 & 0.001 & -0.061 \\
\hline x7305_4 & -0.029 & $\mathbf{0 . 1 5 8}$ & 0.034 & -0.002 & -0.014 \\
\hline x7302_8 & -0.010 & 0.001 & $\mathbf{0 . 5 7 0}$ & 0.000 & -0.008 \\
\hline x7302_9 & 0.000 & 0.000 & $\mathbf{0 . 3 8 6}$ & 0.000 & 0.002 \\
\hline q7307_1 & 0.009 & 0.002 & 0.009 & $\mathbf{0 . 7 1 1}$ & -0.023 \\
\hline q7307_2 & 0.003 & 0.001 & 0.003 & $\mathbf{0 . 2 3 9}$ & -0.008 \\
\hline q7306 & 0.003 & -0.012 & -0.002 & $\mathbf{0 . 0 2 9}$ & 0.015 \\
\hline x7302_2 & 0.082 & 0.111 & 0.051 & -0.001 & $\mathbf{0 . 5 1 2}$ \\
\hline x7302_4 & 0.003 & 0.033 & 0.008 & 0.000 & $\mathbf{0 . 1 9 6}$ \\
\hline x7305_1 & 0.024 & -0.381 & -0.003 & 0.000 & $\mathbf{0 . 1 8 6}$ \\
\hline
\end{tabular}

Table 8 shows the regression weights for the CFA model. It estimates a weight for each indicator (17) in relation to the five dimensions, and the weight provides a way to generate a single measure for each dimension, which uses all the 17 variables. For example, the following equation shows the continuous scale for making decisions where the standardized scores for every variable are multiplied by their appropriate weights and then added together. This technique helps in creating the measures of gender which integrates the effect of other aspects of empowerment. Resulting weighted scores signify a woman's scores on the latent dimensions of gender and help in measuring gender as a system.

Make Decisions $=$

$$
\begin{aligned}
& \text { 0.296*x7302_5+0.131*x7302_10+0.076*x7302_7 } \\
& +0.057 * \mathrm{x} 7302 \_3+0.043 * \mathrm{x} 7302 \_6+0.038 * \mathrm{x} 7302 \_1+0.017 * \mathrm{x} 7305 \_3+0.001 * \mathrm{x} 7305 \_ \\
& 2+-0.029 * \mathrm{x} 7305 \_4+0.01 * \mathrm{x} 7302 \_8+0 * \mathrm{x} 7302 \_9+0.009 * \mathrm{q} 7307 \_1+0.003 * \\
& \mathrm{q} 7307 \_2+0.003 * \mathrm{q} 7306+0.082 * \mathrm{x} 7302 \_2+0.003 * \mathrm{x} 7302 \_4+0.024 * \mathrm{x} 7305 \_1
\end{aligned}
$$

Table 9: Model fit summary (CMIN)

\begin{tabular}{|c|c|c|c|c|c|}
\hline Model & NPAR & CMIN & DF & P & CMIN/DF \\
\hline Default model & 73 & 395.847 & 80 & 0 & 4.948 \\
\hline Saturated model & 153 & 0 & 0 & & \\
\hline Independence model & 17 & 54498.406 & 136 & 0 & 400.724 \\
\hline
\end{tabular}


Table 10: Model fit (RMSEA).

\begin{tabular}{|c|c|c|c|c|}
\hline Model & RMSEA & LO 90 & HI 90 & PCLOSE \\
\hline Default model & 0.024 & 0.022 & 0.026 & 1 \\
\hline Independence model & 0.24 & 0.239 & 0.242 & 0 \\
\hline
\end{tabular}

Table 11: Model fit (CFI)

\begin{tabular}{|c|c|c|c|c|c|}
\hline Model & NFI & RFI & IFI & TLI & CFI \\
\hline & Delta1 & rho1 & Delta2 & rho2 & \\
\hline Default model & 0.993 & 0.988 & 0.994 & 0.990 & 0.994 \\
\hline Saturated model & 1 & & 1 & & 1 \\
\hline Independence model & 0 & 0 & 0 & 0 & 0 \\
\hline
\end{tabular}

Tables 9, 10, and 11 represent three of the fit indices; the first model fit summary is CMIN, where the value must range from 3 to 5 and the value here is (4.984). Then, the Root Mean Square Error of Approximation (RMSEA), which should be 0.05 or lower, and the value here is (0.024). Finally, the Comparative Fit Index (CFI) which should be closer to one, and the value here is (0.994).

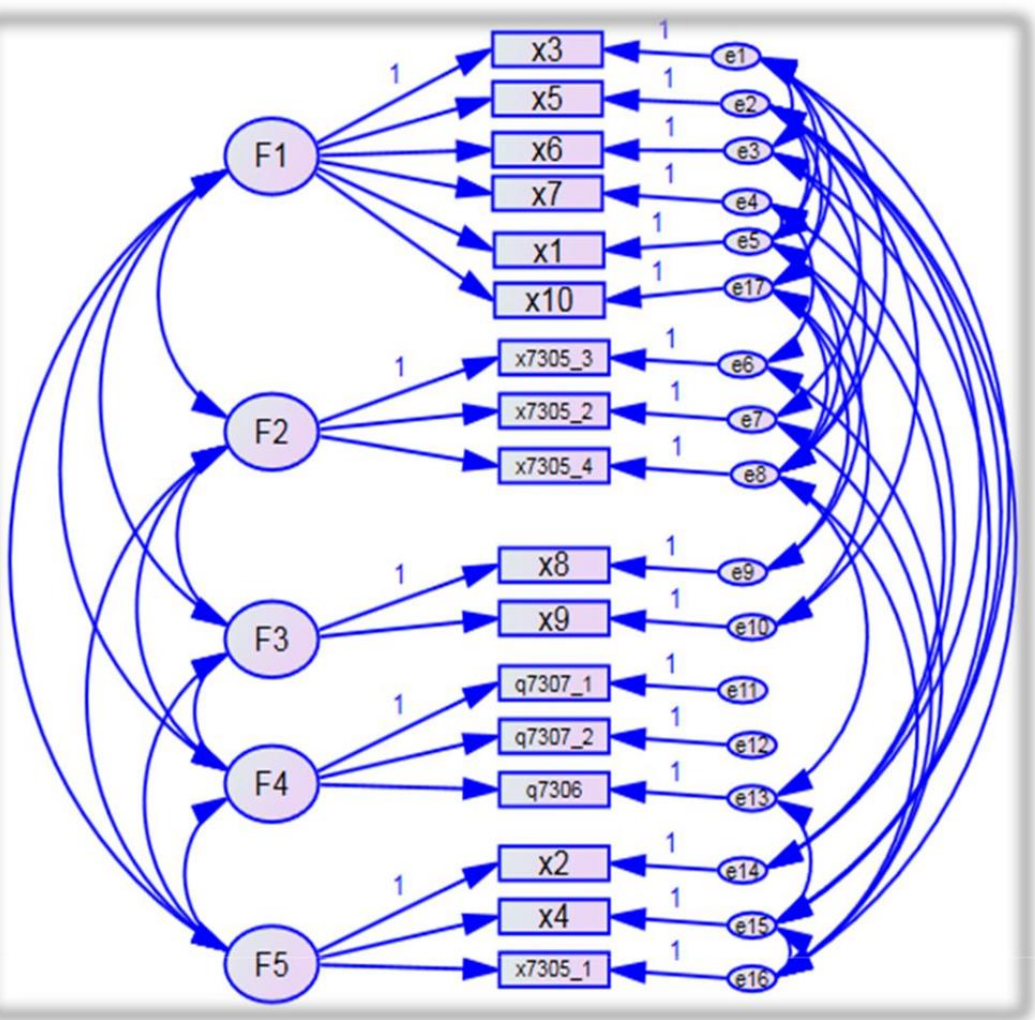

Fig. 2: CFA model of gender and women's empowerment. 


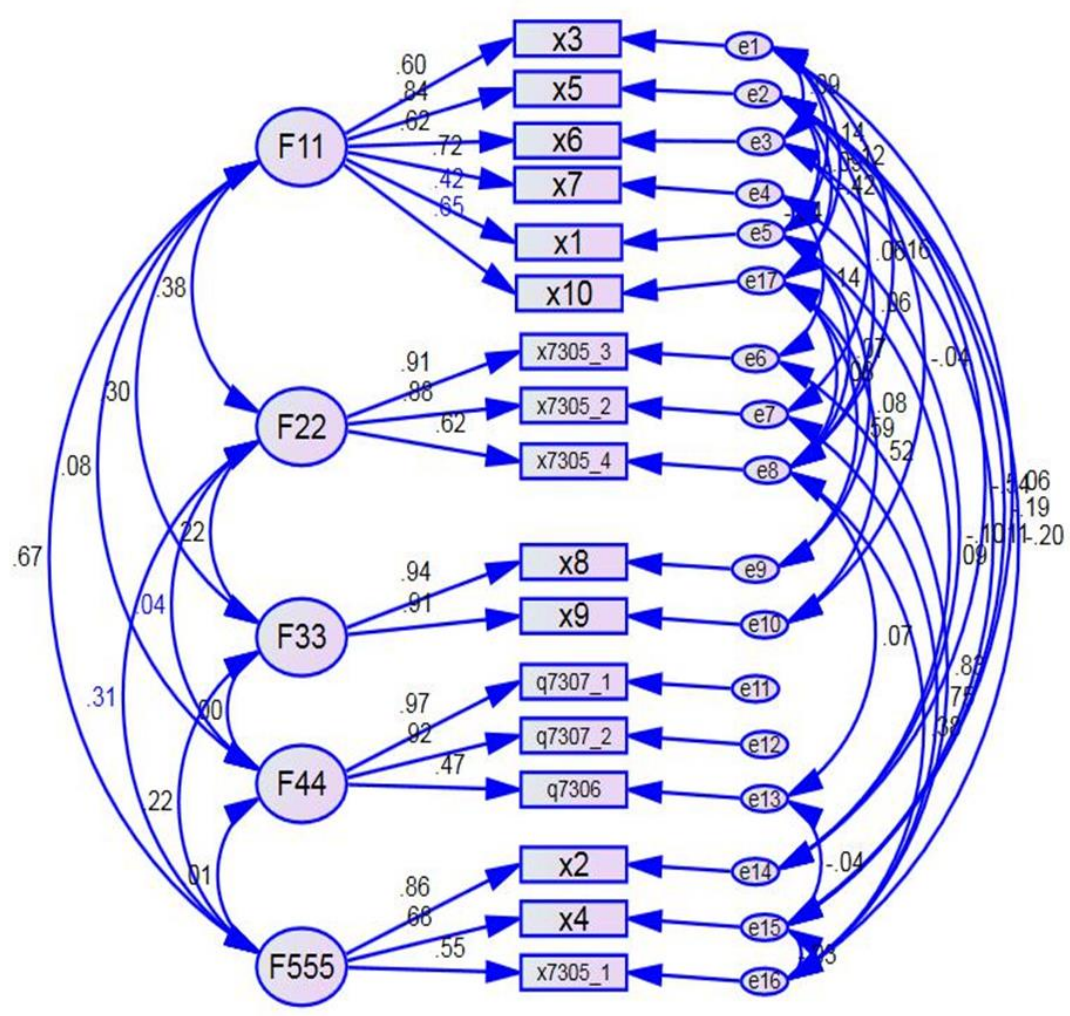

Fig. 3: CFA model of gender and women's empowerment.

Figures 2 and 3 above show the full model, where the five latent dimensions of the gender norms of the women's empowerment are on the left whereas the errors are on the right. The two figures show that the errors and factors are interrelated.

Table 12 shows both the EFA and CFA correlations values, where F1, F2, F3, F4, and F5 represent the EFA values and Factor 1, Factor 2, Factor 3, Factor 4 and Factor 5 represent the CFA values. There is a positive correlation between both techniques, which means that both techniques were able to describe and estimate the data well.

Table 13 shows the Pearson correlation values that reveals that F1 has the greatest value, followed by F3, F5, F2 and the F4 with the least value $(.746, .724, .718, .580$, and .226 respectively) and they were all statistically significant. This means that making decisions has the great effect on gender and women's empowerment. Indeed, this factor included dealing with many people, either firstly, with the doctor or/and the personnel in the local health unit, or secondly, through buying stuff for herself or her children or for the house, or lastly, visiting her family or relatives. This suggests that dealing with different people in different situations may improve women's empowerment. This was followed by 
dealing with the children's school through dealing with the school and teachers daily (factor 3), which in turn means dealing with people too. Also, buying every day's needs and going to the market (factor 5) comes at the third on the effect on the gender and women's empowerment. Taking the children to the doctor or the local health unit or going herself (factor 2) comes at the fourth place, while seeking help from relatives comes last (factor 4). This may suggest that an Egyptian woman prefers dealing with her daily life by herself and not by seeking help from relatives.

Table 12: The correlation between the EFA and CFA models

\begin{tabular}{|c|c|c|c|c|c|c|}
\hline \multicolumn{7}{|c|}{ Correlations (CFA) } \\
\hline \multicolumn{2}{|r|}{ EFA } & \multirow{2}{*}{\begin{tabular}{|c|} 
FACTOR1 \\
$.877^{* *}$
\end{tabular}} & \multirow{2}{*}{\begin{tabular}{|c|} 
FACTOR2 \\
$.186^{* *}$
\end{tabular}} & \multirow{2}{*}{$\frac{\text { FACTOR3 }}{.170^{* *}}$} & \multirow{2}{*}{\begin{tabular}{|c|} 
FACTOR4 \\
$.047^{* *}$
\end{tabular}} & FACTOR5 \\
\hline \multirow{3}{*}{ F1 } & $\begin{array}{c}\text { Pearson } \\
\text { Correlation }\end{array}$ & & & & & $.308^{* *}$ \\
\hline & Sig. (2-tailed) & 0.000 & 0.000 & 0.000 & 0.000 & 0.000 \\
\hline & $\mathrm{N}$ & 6920 & 6920 & 6920 & 6920 & 6920 \\
\hline \multirow{3}{*}{$\mathrm{F} 2$} & $\begin{array}{c}\text { Pearson } \\
\text { Correlation }\end{array}$ & $.223^{* *}$ & $.832^{* *}$ & $.114^{* *}$ & 0.018 & 0.003 \\
\hline & Sig. (2-tailed) & 0.000 & 0.000 & 0.000 & 0.138 & 0.782 \\
\hline & $\mathrm{N}$ & 6920 & 6920 & 6920 & 6920 & 6920 \\
\hline \multirow{3}{*}{ F3 } & $\begin{array}{c}\text { Pearson } \\
\text { Correlation } \\
\end{array}$ & $.138^{* *}$ & $.108^{* *}$ & $.921^{* *}$ & $-.024^{*}$ & $.058^{* *}$ \\
\hline & Sig. (2-tailed) & 0.000 & 0.000 & 0.000 & 0.046 & 0.000 \\
\hline & $\mathrm{N}$ & 6920 & 6920 & 6920 & 6920 & 6920 \\
\hline \multirow{3}{*}{$\mathrm{F} 4$} & $\begin{array}{c}\text { Pearson } \\
\text { Correlation } \\
\end{array}$ & $.029^{*}$ & 0.005 & 0.017 & $.963^{* *}$ & 0.022 \\
\hline & Sig. (2-tailed) & 0.015 & 0.657 & 0.161 & 0.000 & 0.061 \\
\hline & $\mathrm{N}$ & 6920 & 6920 & 6920 & 6920 & 6920 \\
\hline \multirow{3}{*}{ F5 } & $\begin{array}{c}\text { Pearson } \\
\text { Correlation }\end{array}$ & $.494^{* *}$ & $.153^{* *}$ & $.099^{* *}$ & -0.014 & $.784^{* *}$ \\
\hline & Sig. (2-tailed) & 0.000 & 0.000 & 0.000 & 0.237 & 0.000 \\
\hline & $\mathrm{N}$ & 6920 & 6920 & 6920 & 6920 & 6920 \\
\hline
\end{tabular}

Table 13: Pearson Correlation between women's empowerment and the five factors

\begin{tabular}{|c|c|r|r|r|r|r|}
\hline \multicolumn{1}{|c|}{} & $\mathrm{F} 1$ & $\mathrm{~F} 2$ & $\mathrm{~F} 3$ & $\mathrm{~F} 4$ & F5 \\
\hline \multirow{2}{*}{ TOTAL } & $\begin{array}{c}\text { Pearson } \\
\text { Correlation }\end{array}$ & $.746^{* *}$ & $.580^{* *}$ & $.729^{* *}$ & $.226^{* *}$ & $.718^{* *}$ \\
\cline { 2 - 7 } & Sig. (2-tailed) & 0.000 & 0.000 & 0.000 & 0.000 & 0.000 \\
\hline & $\mathrm{N}$ & 6920 & 6920 & 6920 & 6920 & 6920 \\
\hline
\end{tabular}


Table 14: Weighted measures of women's empowerment

\begin{tabular}{|c|c|c|c|}
\hline & Mean & Std. & Median \\
\hline & & Deviation & \\
\hline Overall Empowerment & 8.291 & 1.930 & 8.249 \\
\hline F1 & 1.479 & 0.395 & 1.496 \\
\hline F2 & 1.609 & 0.548 & 1.707 \\
\hline F3 & 1.130 & 1.019 & 1.014 \\
\hline F4 & 1.757 & 0.380 & 1.955 \\
\hline F5 & 2.316 & 0.681 & 2.435 \\
\hline
\end{tabular}

Table 15: Mann-whitney test

\begin{tabular}{|c|c|c|c|c|c|}
\hline \multicolumn{6}{|c|}{ Ranks } \\
\hline \multicolumn{2}{|c|}{ Women's empowerment } & $\mathrm{N}$ & Mean Rank & $\mathrm{Z}$ & $\begin{array}{l}\text { Asymp.Sig. } \\
\text { (2-tailed) }\end{array}$ \\
\hline \multirow{3}{*}{$\mathrm{x} 1$} & Not empowered & 3460 & 3009.93 & \multirow{3}{*}{-20.997} & \multirow{3}{*}{0.001} \\
\hline & Empowered & 3460 & 3911.07 & & \\
\hline & Total & 6920 & & & \\
\hline \multirow{3}{*}{$\mathrm{x} 2$} & Not empowered & 3460 & 2533.49 & \multirow{3}{*}{-42.056} & \multirow{3}{*}{0.001} \\
\hline & Empowered & 3460 & 4387.51 & & \\
\hline & Total & 6920 & & & \\
\hline \multirow{3}{*}{$\mathrm{x} 3$} & Not empowered & 3460 & 2842.25 & \multirow{3}{*}{-28.174} & \multirow{3}{*}{0.001} \\
\hline & Empowered & 3460 & 4078.75 & & \\
\hline & Total & 6920 & & & \\
\hline \multirow{3}{*}{$\mathrm{x} 4$} & Not empowered & 3460 & 2740.27 & \multirow{3}{*}{-33.434} & \multirow{3}{*}{0.001} \\
\hline & Empowered & 3460 & 4180.73 & & \\
\hline & Total & 6920 & & & \\
\hline \multirow{3}{*}{$x 5$} & Not empowered & 3460 & 2582.16 & \multirow{3}{*}{-40.220} & \multirow{3}{*}{0.001} \\
\hline & Empowered & 3460 & 4338.84 & & \\
\hline & Total & 6920 & & & \\
\hline \multirow{3}{*}{$\mathrm{x} 6$} & Not empowered & 3460 & 2787.56 & \multirow[b]{3}{*}{-30.200} & \multirow{3}{*}{0.001} \\
\hline & Empowered & 3460 & 4133.44 & & \\
\hline & Total & 6920 & & & \\
\hline \multirow{3}{*}{$\mathrm{x} 7$} & Not empowered & 3460 & 2631.35 & \multirow{3}{*}{-37.506} & \multirow{3}{*}{0.001} \\
\hline & Empowered & 3460 & 4289.65 & & \\
\hline & Total & 6920 & & & \\
\hline \multirow{3}{*}{$\mathrm{x} 8$} & Not empowered & 3460 & 2362.65 & \multirow{3}{*}{-47.916} & \multirow{3}{*}{0.001} \\
\hline & Empowered & 3460 & 4558.35 & & \\
\hline & Total & 6920 & & & \\
\hline \multirow{3}{*}{$\mathrm{x} 9$} & Not empowered & 3460 & 2382.83 & \multirow{3}{*}{-47.217} & \multirow{3}{*}{0.001} \\
\hline & Empowered & 3460 & 4538.17 & & \\
\hline & Total & 6920 & & & \\
\hline & Not empowered & 3460 & 2720.73 & & \\
\hline $\mathrm{x} 10$ & Empowered & 3460 & 4200.27 & -32.734 & 0.001 \\
\hline & Total & 6920 & & & \\
\hline & Not empowered & 3460 & 2929.8 & & \\
\hline x7305_1 & Empowered & 3460 & 3991.13 & & 0.001 \\
\hline & Total & 6920 & & -24.716 & \\
\hline
\end{tabular}




\begin{tabular}{|c|c|c|c|c|c|}
\hline \multirow{3}{*}{ x7305_2 } & Not empowered & 3460 & 2770.68 & \multirow{3}{*}{-33.445} & \multirow{3}{*}{0.001} \\
\hline & Empowered & 3460 & 4150.32 & & \\
\hline & Total & 6920 & & & \\
\hline \multirow{3}{*}{ x7305_3 } & Not empowered & 3460 & 2739.84 & \multirow{3}{*}{-34.954} & \multirow{3}{*}{0.001} \\
\hline & Empowered & 3460 & 4181.16 & & \\
\hline & Total & 6920 & & & \\
\hline \multirow{3}{*}{ x7305_4 } & Not empowered & 3460 & 2989.36 & \multirow{3}{*}{-24.959} & \multirow{3}{*}{0.001} \\
\hline & Empowered & 3460 & 3931.64 & & \\
\hline & Total & 6920 & & & \\
\hline \multirow{3}{*}{ q7306 } & Not empowered & 3460 & 3377.50 & \multirow{3}{*}{-5.685} & \multirow{3}{*}{0.001} \\
\hline & Empowered & 3460 & 3543.50 & & \\
\hline & Total & 6920 & & & \\
\hline \multirow{3}{*}{ q7307_1 } & Not empowered & 3460 & 3239.00 & \multirow{3}{*}{-13.287} & \multirow{3}{*}{0.001} \\
\hline & Empowered & 3460 & 3682.00 & & \\
\hline & Total & 6920 & & & \\
\hline \multirow{3}{*}{ q7307_2 } & Not empowered & 3460 & 3242.50 & \multirow{3}{*}{-12.744} & \multirow{3}{*}{0.001} \\
\hline & Empowered & 3460 & 3678.50 & & \\
\hline & Total & 6920 & & & \\
\hline
\end{tabular}

Table 16: Mann-whitney test and demographic variables

\begin{tabular}{|c|c|c|c|c|c|}
\hline \multicolumn{6}{|c|}{ Ranks } \\
\hline \multicolumn{2}{|c|}{ Women's empowerment } & \multirow{2}{*}{$\frac{N}{3460}$} & \multirow{2}{*}{$\begin{array}{c}\text { Mean } \\
\text { Rank } \\
2965.27\end{array}$} & Z & $\begin{array}{l}\text { Asymp.Sig. (2- } \\
\text { tailed) }\end{array}$ \\
\hline \multirow{3}{*}{$\begin{array}{l}\text { Age (Ten } \\
\text { groups) }\end{array}$} & Not empowered & & & \multirow{3}{*}{-22.179} & \multirow{3}{*}{0.000} \\
\hline & Empowered & 3460 & 3955.73 & & \\
\hline & Total & 6920 & & & \\
\hline \multirow{3}{*}{$\begin{array}{l}\text { Quintiles of } \\
\text { household } \\
\text { Wealth }\end{array}$} & Not empowered & 3460 & 3349.46 & \multirow{3}{*}{-4.722} & \multirow{3}{*}{0.000} \\
\hline & Empowered & 3460 & 3571.54 & & \\
\hline & Total & 6920 & & & \\
\hline \multirow{3}{*}{$\begin{array}{c}\text { Educational } \\
\text { Attainment } \\
\text { (6 } \\
\text { Categories, } \\
\text { age } 10+)\end{array}$} & Not empowered & 3454 & 3487.97 & \multirow{3}{*}{-1.544} & \multirow{3}{*}{0.123} \\
\hline & Empowered & 3450 & 3416.99 & & \\
\hline & Total & 6904 & & & \\
\hline
\end{tabular}


The last Table, Table 16 shows some demographic variables with regards to women's empowerment. It revealed that older women are more empowered than younger ones. Also, women who are more advantaged (the highest two wealth index classes) are more empowered than the poorer. Finally, education seemed to have no effect in empowering Egyptian women, since the education of the study's sample were intermediate, or less for about $81.4 \%$. Moreover, $27 \%$ of the samples were illiterate, which may suggest that gender norms play a greater role than education in empowering women in Egypt.

\section{Conclusion and future work}

Gender can be theorized as a set of underlying systematic expectations for the behavior of women, and the empowerment of women represents the relative exercise of their power within that system. Empowering woman is considered one of the most important issues in the sustainable development process for many nations worldwide.

Moreover, the ability to assess gender and women's empowerment using quantitative techniques gives demographers a better understanding of their impact on the demographic process.

As a result, the main aim of this study was to explore the association between gender norms and married women's empowerment in Egypt. This study adopted EFA and CFA to determine the number of factors and their relations. It also constructed a weighted measure of women's empowerment to the results to compare them to simple scale measures.

The results of the EFA analysis revealed five dimensions that were: (1) making decisions, (2) mobility, (3) dealing with the children's school, (4) seeking help from the relatives, and (5) the daily decision within the household.

Findings showed that the first factor - making decisions- had the greatest effect on empowering Egyptian women, whereas seeking help from relatives had the least effect. In addition to that, it was found that older women seemed to be more empowered than younger women. Moreover, women who were on the top of the two wealth indexes were found to be more empowered. Since the educational level of most of the sampled women were intermediate or less, the education seemed to have no effect, or that gender norms might have a greater influence on empowerment than education.

Suggestions for future research is to examine Egyptian women empowerment using more recent data and introducing the economic dimensions. 


\section{References}

Aghababa, S., Nasiripour, A. A., Maleki, M., \& Gohari, M. (2015). Demographic characteristics of donors: an exploratory and confirmatory factor analysis in health care of Iran. Current Science, 1704-1708.

ELMPS. (2012). Egypt Labor Market Panel Survey.

Eo, Y. S., Kim, Y. H., \& Lee, N. Y. (2014). Path analysis of empowerment and work effectiveness among staff nurses. Asian Nursing Research, 8(1), 42-48.

Ewerling, F., Lynch, J. W., Victora, C. G., van Eerdewijk, A., Tyszler, M., \& Barros, A. J. (2017). The SWPER index for women's empowerment in Africa: development and validation of an index based on survey data. The Lancet Global Health, 5(9), e916-e923.

Hafiz, B., \& Shaari, J. A. N. (2013). Confirmatory factor analysis (CFA) of first order factor measurement model-ICT empowerment in Nigeria. International Journal of Business Management and Administration, 2(5), 081-088.

Izquierdo Alfaro, I., Olea Díaz, J., \& Abad, F. J. (2014). Exploratory factor analysis in validation studies: Uses and recommendations. Psicothema, Vol.26, No.4, 395 400

Kabeer, N. (1999). Resources, agency, achievements: Reflections on the measurement of women's empowerment. Development and change, 30(3), 435-464.

Kabeer, N. (2005). Gender equality and women's empowerment: A critical analysis of the third millennium development goal 1. Gender \& Development, 13(1), 13-24.

Malhotra, A. (2003). Conceptualizing and measuring women's empowerment as a variable in international development. Measuring Empowerment: CrossDisciplinary Perspectives, Washington, DC.

Martin, L., Kidd, M., \& Seedat, S. (2016). Anxiety sensitivity in school attending youth: Exploratory and confirmatory factor analysis of the 18-item CASI in a multicultural South African sample. Frontiers in Psychology, 6, 1996.

Roy, C., Chatterjee, S., \& Dutta Gupta, S. (2018). Women Empowerment Index: Construction of a Tool to Measure Rural Women Empowerment Level in India. Available at SSRN 3357543. 
Sen, G. (2013). Gender equality in the Post-2015 development agenda: Lessons from the MDGs. IDS bulletin, 44(5-6), 42-48.

Sibanda, W., \& Pretorius, P. D. (2014). Exploratory factor analysis of demographic characteristics of antenatal clinic attendees and their association with HIV risk. Mediterranean Journal of Social Sciences, 5(20), 303.

Suhr, D. (2006). Exploratory or Confirmatory Factor Analysis? Proceedings of the 31st Annual SAS? Users Group International Conference. Cary, NC: SAS Institute Inc., Paper Number: 200-31.

Tazi-Preve, I. M. (2007). Demography and gender. Beginning Australian Population Studies. The Australian National University, Canberra. Accessed, 10.

Tongsilp, A. (2013). A path analysis of relationships between factors with achievement motivation of students of private universities in Bangkok, Thailand. Procedia-Social and Behavioral Sciences, 88, 229-238.

UNDP. (2018). Human Development Indices and Indicators. 2018 Statistical Update. United Nations Development Programme.

Williams, J. (2005). Measuring gender and women's empowerment using confirmatory factor analysis. Population Program, Institute of Behavioural Science, University of Colorado, Boulder.

Yanwaree, N. (2013). The Effect of Using Learning Activities based on PATH Method in Sexuality and Health Subject. Procedia-Social and Behavioral Sciences, 88, 225-228. 